\title{
PERAN STIMULASI ORANGTUA TERHADAP PERKEMBANGAN ANAK BALITA KELUARGA MISKIN
}

(The Role of Parent's Stimulation on Development of Under-Five Years Old Children in Poor Family)

\author{
Dodik Briawan ${ }^{1}$ dan Tin Herawati ${ }^{2}$
}

\begin{abstract}
Parents have an important role in childcare. Not all parents, especially fathers are able to practice child caring in proper and adequate way. The objective of this research was to analyze relationship of stimulation given by parents to the development of their children. The research was carried out in surrounding Bogor Agricultural University (IPB) Darmaga Campus. Samples consisted of two groups of children, 37 normal and 37 stunting were drawn randomly from the participants of World Food Program (WFP) feeding project in Bogor District. Data were collected from April to May 2005. The instruments used to measure stimulation and child development were referred to Ministry of Health recommendation used by Posyandu cadres. Spearman rank correlation and descriptive statistics were applied to analyze the data. Research results showed that family characteristics between the two groups are relatively the same. The age of stunting children was younger and period of sickness was shorter than that of normal children. It was also found that not all children get adequate stimulation. Stimulation was practiced by only 48-72\% family. After 18 months old the children were intensively stimulated by the largest portion of mothers. The stunting children received stimulation intensively beginning at earlier age and the stimulation mostly practiced by mother. Only small part of stimulation was taken by father after the children reach one year. At the average, score stimulation was low in 21-22\% normal and stunting children. The stimulation practiced by parents significantly related to child development.
\end{abstract}

Key Words: Parent's Stimulation, Child Development, Under-Five Years Old Children, Children in Poor Family

\section{PENDAHULUAN}

Pembangunan nasional bertujuan meningkatkan kualitas sumberdaya manusia secara berkesinambungan dan berkelanjutan. Kualitas sumberdaya manusia ditentukan oleh keberhasilan tumbuh kembang pada masa kanak-kanak (Depkes RI 2000). Investasi yang dimulai sejak dini (usia anak-anak) dianggap paling menguntungkan di dalam pembangunan SDM. Faktor utama yang mempengaruhi tumbuh kembang anak diantaranya adalah faktor gizi, kesehatan dan pengasuhan (caring) yang terkait satu sama lain. Hasil studi Zeitlin (2000) menunjukkan bahwa anak yang diasuh dengan baik akan memiliki tingkat perkembangan yang baik. Demikian juga anak yang memiliki status gizi baik akan memiliki tingkat perkembangan yang baik (Grantham Mc-Gregor 1995).
Dalam rangka mempersiapkan anak supaya tumbuh dan berkembang baik maka perlu pengasuhan dari orang-orang di sekitarnya terutama orang tuanya sendiri, yaitu ayah dan ibu. Namun kenyataannya dalam kehidupan keluarga umumnya di Indonesia yang paling utama berfungsi sebagai pengasuh adalah ibu (Gunarsa \& Gunarsa 1995)

Hasil penelitian BKKBN di Jawa Timur dan Manado menunjukkan, 50\% ibu menyatakan pengasuhan anak adalah tugas ibu, dan $40 \%$ menyatakan pengasuhan anak adalah tanggung jawab ayah dan ibu. Hal ini masih menunjukkan bahwa peran pengasuhan anak lebih condong dilakukan oleh ibu (Megawangi 1999). Padahal untuk mencapai perkembangan anak yang optimal perlu keterlibatan ayah dalam pengasuhan. Ayah mempunyai tanggung jawab yang 
sama dengan ibu dalam pengasuhan sehingga anak dapat mencapai perkembangan fisik, komunikasi, kognisi dan sosial secara optimal. Meski demikian tetap terdapat pembagian peran ayah dan ibu yang spesifik sesuai kodrat dan gender. Pengasuhan yang dilakukan ayah dengan anak lebih banyak melibatkan aktifitas fisik, sedangkan ibu cenderung melibatkan aktifitas verbal (Nurhaena 1995). Hasil penelitian Kasuma (2001) di Nusa Tenggara Timur menunjukkan bahwa peran ayah dalam pengasuhan mempunyai pengaruh nyata pada tingkat perkembangan anak.

Menurut Engle (1999) peranan anggota keluarga terutama ayah tidak boleh diabaikan, ayah merupakan wasit didalam pengambilan keputusan tentang perawatan anak, serta di dalam pemberian air susu ibu (ASI). Peranan anggota keluarga lainnya dalam perkembangan bayi, pada bulan pertama, secara tidak langsung adalah memberi dukungan emosional kepada ibu. Setelah bulan pertama, peranan anggota keluarga secara langsung tertuju kepada kesehatan dan gizi bayi (Zeitlin 2000). Selanjutnya Dagun (1990) juga menyatakan bahwa partisipasi ayah dalam membina pertumbuhan fisik dan psikologis anak tidak kalah pentingnya dengan peranan ibu dalam mengasuh anak. Oleh karena itu untuk mendapatkan anak yang tumbuh dan berkembang secara optimal perlu pengasuhan yang lengkap dari kedua orang tuanya.

Banyak penelitian yang melaporkan pentingnya peranan ibu dalam tumbuh kembang anak. Khomsan (2004) dan Widayani (2000) melaporkan bahwa peranan ibu selaku pengasuh anak dan pendidik di dalam keluarga dapat mempengaruhi tumbuh kembang anak. Demikian juga dengan penelitian Jus'at (2000) yang dilakukan di daerah Bogor Jawa Barat menyimpulkan bahwa interaksi ibu dan anak mempengaruhi keadaan gizi anak. Hartoyo (2001) melaporkan bahwa pertumbuhan anak akan berlangsung baik apabila adanya partisipasi anggota keluarga. Demikian juga halnya penelitian yang dilakukan Martianto (1998) yang melaporkan bahwa pemberian stimulasi terhadap perkembangan anak menurun dengan tidak adanya partisipasi anggota keluarga terutama ayah. Keluarga mempunyai peranan penting dan strategis dalam meningkatkan pertumbuhan dan perkembangan anak usia dini (Hartoyo 1998). UNICEF (2002) menyatakan bahwa anak memerlukan perhatian dari orangtuanya bukan hanya dari ibunya saja. Oleh karena itu peneliti tertarik untuk melakukan penelitian peranan orangtua di dalam memberikan stimulasi tumbuh kembang anak.

Tujuan umum penelitian ini adalah untuk mengetahui peranan orangtua di dalam melakukan stimulasi perkembangan dan pertumbuhan pada anak balita dengan status gizi yang berbeda pada keluarga miskin. Sedangkan tujuan khususnya adalah : (1) membandingkan karakteristik rumah tangga dan anak balita yang mempunyai status gizi normal dan kurang; (2) mengkaji stimulasi orangtua dan anggota rumah tangga lainnya didalam memberikan stimulasi perkembangan anak; (3) mengkaji hubungan stimulasi terhadap perkembangan anak yang mempunyai status gizi normal dan kurang; dan (4) mengkaji hubungan perkembangan dengan status gizi anak balita.

\section{METODE PENELITIAN}

Desain, Tempat dan Waktu

Penelitian ini bersifat deskriptif dan menggunakan metode survey dengan desain cross-sectional study. Penelitian dilakukan di Kecamatan Dramaga Kota Bogor Provinsi Jawa Barat pada Bulan April sampai dengan Bulan Mei 2005. Lokasi dipilih secara purposive dengan beberapa pertimbangan, yaitu merupakan wilayah sub urban di Kota Bogor, kemudahan untuk akses ke tempat penelitian, dekat dengan kampus IPB Darmaga. Kerangka contoh yang 
digunakan berasal dari studi World Food Programme (WFP) tentang efikasi pemberian biskuit yang diperkaya dengan mineral mikro untuk anak balita. Hal ini memudahkan untuk menjalin kerjasama dengan keluarga responden.

\section{Penarikan Contoh}

Balita yang menjadi contoh dalam penelitian ini adalah balita dengan kategori status gizi normal dan kategori status gizi stunting berdasarkan indeks TB-U. Contoh penelitian berasal dari studi yang dilakukan WFP untuk contoh penelitian WFP dengan persyaratan berasal dari keluarga miskin (Pra-KS dan KS-I). Dari pendataan dan data sekunder dari kelurahan serta catatan kader diperoleh 240 orang anak balita yang cocok untuk contoh penelitian WFP. Dari 240 anak tersebut diambil 120 anak sebagai contoh penelitian WFP. Dari 120 contoh WFP terdapat 37 Balita yang stunting (TB-U $<-2.0$ $\mathrm{SD})$

Jumlah ini kemudian ditambah dengan 37 orang balita lainnya yang status gizinya normal. Penentuan 37 balita berstatus gizi normal dipilih berdasarkan lokasi tempat tinggal, dengan keadaan sosial ekonomi kurang lebih sama. Bila dalam sebuah desa ditemukan satu orang balita stunting maka dari desa tersebut dipilih secara acak satu orang balita yang status gizinya normal.

\section{Jenis dan Cara Pengumpulan Data}

Data primer yang dikumpulkan meliputi peran keluarga dalam stimulasi tumbuh kembang anak. Peran orangtua diukur dari kegiatan yang dilakukan untuk memberikan stimulasi pada setiap tahapan perkembangan anak (Depkes dan JICA 2000). Tahapan perkembangan anak dikategorikan berdasarkan umur 0-30 hari, 1-4, 4-6, 6-9, 9-12, 12-18, 18-24 bulan, 2-3, 3-4, 4-5 tahun. Data tersebut di atas dikumpulkan melalui wawancara dengan menggunakan kuesioner. Sedangkan data sekunder yang telah dikumpulkan WFP yang digunakan adalah karakteristik sosial ekonomi keluarga (meliputi identitas keluarga, tingkat pendidikan, pendapatan dan kondisi tempat tinggal), dan karakteristik anak yang meliputi data identitas anak, berat badan, tinggi badan, dan riwayat kesehatan anak.

\section{Pengolahan dan Analisis Data}

Setelah data dikumpulkan selanjutkan akan melalui proses editing dan pengkodean terlebih dahulu sebelum diolah dan dianalisis. Data pendidikan keluarga yang diukur meliputi lama pendidikan (dinyatakan dalam tahun) dan jenjang pendidikan (dikategorikan menjadi tidak sekolah, taman kanak-kanak, SD, SMP, SMA dan PT). Data pendapatan keluarga setelah dihitung rata-ratanya dikategorikan atas dua kategori yaitu tinggi bila sama dengan dan di atas rata-rata dan rendah bila di bawah ratarata.

Data keadaan kesehatan diukur dari kejadian sakit sejak satu bulan yang lalu yang meliputi jenis penyakit, frekuensi sakit dan lama sakit. Variabel yang digunakan dalam uji statistik adalah variabel lama sakit dengan asumsi bahwa lama sakit merupakan indikator yang dapat menggambarkan keadaan kesehatan anak. Berdasarkan lama hari sakit, keadaan kesehatan anak dibagi atas tinggi bila pernah sakit $\geq 2$ hari dan rendah bila $<2$ hari atau tidak pernah sakit.

Data stimulasi yang dilakukan oleh orangtua diberi nilai 1 bila dilakukan dan 0 bila tidak dilakukan. Sedangkan data perkembangan anak dinilai berdasarkan pencapaian setiap tahapan yang mampu dilakukan oleh anak menurut kelompok umurnya. Apabila mampu dilakukan diberi skor 1 dan tidak mampu dilakukan diberi skor 0 . Data ini kemudian dijumlahkan, dirata-ratakan, dan dicari standar deviasinya (SD), selanjutnya dikategorikan menjadi baik bila nilai rata-rata $>+1 \mathrm{SD}$, sedang bila -1 $\mathrm{SD}<$ nilai $<+1 \mathrm{SD}$, dan kurang $<-1 \mathrm{SD}$. 
Data perkembangan psikososial diberi nilai 1 untuk jenis perkembangan yang berhasil ditempuh balita dan nilai 0 untuk yang tidak berhasil. Kemudian dikategorikan sama dengan cara kategori stimulasi psikososial.

Setelah mengalami proses pengolahan di atas maka data dianalisis secara deskriptif dan inferensia dengan menggunakan perangkat lunak SPSS versi 10.0 for window. Hubungan antara berbagai variabel (pendidikan, pendapatan dan praktik pemberian makanan) dengan asupan gizi anak dianalisis dengan uji korelasi Rank Spearman. Demikian juga dengan hubungan berbagai variabel (praktik pemberian makanan, praktik kesehatan dan sanitasi lingkungan) dengan keadaan kesehatan. Analisis selanjutnya dilakukan berdasarkan kelompok balita yang pertumbuhannya normal dan yang stunting. Untuk menguji perbedaan nilai variabel penelitian dilakukan dengan uji Kruskal Wallis dan uji beda-t.

\section{HASIL DAN PEMBAHASAN \\ Karakteristik Rumah tangga}

Pada umumnya rata-rata umur ibu rumah tangga dibawah 30 tahun, dengan persentase tertinggi (32.\%) terdapat pada selang 21-25 tahun dan pada selang 26-30 tahun sebanyak $28.2 \%$. Rata-rata umur isteri secara keseluruhan adalah 27.0 tahun. Jika dilihat berdasarkan status gizi, persentase tertinggi $(37.5 \%)$ umur ibu pada kelompok status gizi normal terdapat pada selang 21-25 tahun. Persentase yang cukup tinggi juga $(31.3 \%)$ ditemukan pada selang 31-35 tahun. Lain halnya pada kelompok status gizi kurang, persentase tertinggi $(35.9 \%)$ umur ibu ditemukan pada selang 26-30 tahun. Rata-rata umur ibu pada kelompok status gizi normal adalah 27.25, sedangkan pada kelompok status gizi kurang 26.79 tahun. Hasil uji statistik menunjukkan tidak terdapat perbedaan nyata antara umur ibu pada kelompok status gizi kurang dengan umur ibu pada kelompok status gizi kurang $(\alpha<0.05)$.

Persentase tertinggi $(28.2 \%)$ umur suami berada pada selang 31- 35 tahun, dengan rata-rata 32.79 tahun. Keadaan yang sama juga terlihat pada kelompok anak dengan status gizi normal $(25.0 \%)$ dan status gizi kurang $(30.8 \%)$. Rata-rata umur ayah pada kelompok status gizi normal adalah 31.66 tahun, sedangkan pada kelompok status gizi kurang 33.72 tahun. Hasil uji statistik menunjukkan tidak terdapat perbedaan nyata antara umur ayah pada kelompok status gizi kurang dengan kelompok status gizi kurang $(\alpha<0.05)$.

Sebagian besar pendidikan ibu (83.1\%) dan ayah (76.1\%) adalah sekolah dasar (SD) dengan rata-rata lama pendidikan ibu 5.80 tahun dan 6.79 tahun. Tidak terdapat perbedaan lama pendidikan ibu pada kelompok status gizi normal dengan kelompok status gizi kurang $(\alpha<0.05)$. Berbeda dengan tingkat pendidikan ibu, pada suami sebanyak $1.3 \%$ berpendidikan perguruan tinggi dan tidak ditemukan ayah yang tidak sekolah. Jika dilihat berdasarkan status gizi, rata-rata lama pendidikan ayah pada kelompok status gizi normal adalah 6.41 tahun dan pada kelompok status gizi kurang 7.10 tahun Hasil uji statistik tidak menunjukkan lama pendidikan KK pada kelompok status gizi normal lebih rendah dibandingkan dengan kelompok status gizi kurang $(\alpha<0.05)$.

Sebagian besar ibu (87.3\%) adalah sebagai ibu rumah tangga, baik pada kelompok status gizi normal maupun kurang. Walaupun demikian juga ditemukan ibu yang bekerja sebagai karyawan $(1.4 \%)$, buruh $(8.5 \%)$ dan wiraswasta $(2.8 \%)$. Hampir semua ayah memiliki pekerjaan, dan hanya $1.4 \%$ yang tidak memiliki pekerjaan. Ayah yang tidak bekerja ditemukan pada kelompok status gizi normal. Sebagian besar ayah (71.8\%) bekerja sebagai buruh dan sisanya bekerja wiraswasta $(11.3 \%)$, honorer $(4.2 \%)$, karyawan $(9.9 \%)$, dan tani $(1.4 \%)$. 
Persentase tertinggi (52.1\%) kategori pendapatan rumah tangga contoh berada pada selang Rp 100.000-Rp 500.000 per bulan. Secara keseluruhan rata-rata pendapatan rumah tangga adalah Rp 550.746. Jika dilihat berdasarkan kelompok status gizi maka pada kelompok status gizi normal, persentase tertinggi (50.0\%) ibu memiliki kategori pendapatan antara $R p \quad 500.001-R p \quad 1.000 .000$, dengan rata-rata pendapatan keluarga/bulan adalah $\mathrm{Rp}$ 561.093. Sedangkan pada kelompok status gizi kurang, persentase tertinggi (56.4\%) responden memiliki pendapatan keluarga antara Rp 100.000-Rp 500.000 dengan rata-rata pendapatan rumah tangga/bulan adalah $\mathrm{Rp}$ 542.256. Walaupun demikian hasil uji statistik tidak menunjukkan perbedaan yang nyata antara pendapatan keluarga/bulan pada kelompok status gizi normal dengan status gizi kurang $(\alpha<0.05)$.

Sebanyak $59.2 \%$ contoh memiliki jumlah rumah tangga kebanyakan anggota keluarga inti dengan jumlah lebih dari 4 orang dan sisanya (40.8\%) $\leq 4$ orang. Rata-rata jumlah anggota rumah tangga adalah 5.1 orang. Jika dilihat berdasarkan kelompok status, maka kelompok status gizi kurang memiliki lebih banyak (5.3 orang) jumlah anggota rumah tangga dibandingkan kelompok status gizi normal (4.75 orang). Walaupun secara statistik tidak menunjukkan perbedaan yang nyata antara jumlah anggota rumah tangga pada kelompok status gizi normal dengan status gizi kurang $(\alpha<0.05)$.

Sebagian besar ibu (77.5\%) memiliki jumlah balita satu orang (Tabel 7). Rata-rata jumlah balita pada status gizi normal adalah 1.28 orang dan pada kelompok status gizi kurang 1.18 orang. Hasil uji statistik tidak menunjukkan perbedaan yang nyata antara pendapatan keluarga/bulan pada kelompok status gizi normal dengan status gizi kurang $(\alpha<0.05)$.
Keadaan Lingkungan Rumah

$$
\text { Pada umumnya }
$$

responden memiliki tempat tinggal yang permanen. Sedangkan untuk alat penerangan, semuanya $(100 \%)$ memakai listrik dan lebih dari $90 \%$ sumber energi yang digunakan adalah minyak tanah.

Persentase tertinggi (63.4\%) responden menggunakan sumur sebagai sumber air. Sumber air lain yang digunakan responden dalam penelitian ini adalah mata air (23.9\%), sungai $(9.9 \%)$ dan PAM (2.8\%). Jika dilihat berdasarkan kelompok status gizi maka sumber air yang banyak digunakan adalah sumur.

Pada umumnya $(62.0 \%)$ responden tidak memiliki septik tank. Selain itu juga ventilasi rumah yang dimiliki responden dalam kondisi yang cukup. Jika dililhat berdasarkan kelompok status gizi, maka ventilasi rumah yang buruk lebih banyak dimiliki oleh keluarga balita yang status gizi normal yaitu $34.4 \%$, sedangkan pada kelompok status gizi kurang sebanyak $20.5 \%$. Keadaan lain yang cukup memprihatinkan adalah lebih dari $90 \%$ responden tidak memiliki tempat sampah. Kondisi yang sama juga terjadi pada kelompok status gizi kurang dan status gizi normal

\section{Karakteristik Anak Balita}

Persentase tertinggi (54.9\%) jenis kelamin anak pada penelitian ini adalah laki-laki. Keadaan tersebut juga nampak pada kelompok status gizi normal, dimana jumlah anak yang jenis kelamin laki-laki sebanyak $65.6 \%$. Sedangkan pada kelompok status gizi kurang, jenis kelamin anak perempuan menempati persentase paling tinggi yaitu $53.8 \%$.

Berdasarkan hasil analisis sebaran umur anak maka dapat dilihat pada Gambar 1 bahwa sebagian besar anak berumur lebih dari 24 bulan dan sebaran terbanyak terdapat pada umur 25 dan 26 bulan. Rata-rata umur anak secara keseluruhan adalah 27.99 bulan. Jika dilihat berdasarkan 
kelompok status gizi maka umur anak pada kedua kelompok status gizi pada umumnya berada antara 25-60 bulan. Jika dilihat berdasarkan kelompok status gizi, rata-rata umur anak pada kelompok status gizi normal adalah 25.75 bulan dan pada kelompok status gizi kurang 29.82 bulan. Hasil uji statistik menunjukkan terdapat perbedaan yang nyata antara umur anak pada kelompok status gizi normal dengan status gizi kurang $(\alpha<0.05)$.

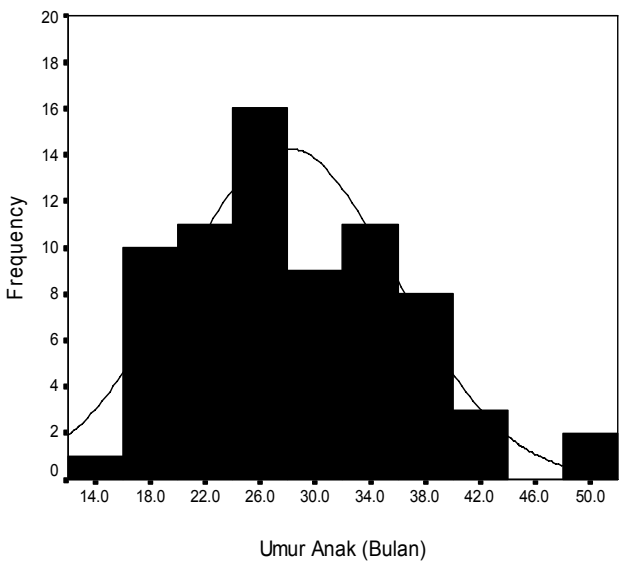

Gambar 1. Sebaran Umur Contoh Anak Balita

Tingkat Morbiditas Anak

Pada umumnya anak (66.2\%) pernah mengalami sakit selama sebulan terakhir. Jumlah anak yang pernah sakit pada kelompok status gizi kurang lebih tinggi (74.4\%) dibandingkan kelompok status gizi normal (56.2\%) (Tabel 1). Menurut Aritonang (1996) kurang gizi adalah faktor prakondisi yang memudahkan anak mendapat infeksi, khususnya infeksi saluran pernapasan dan diare. Selanjutnya Victoria, et.al (1999) menyatakan bahwa anak-anak yang kurang gizi menyebabkan rusaknya sistem imun sehingga mudah terkena sakit.

Tabel 1. Sebaran Anak Berdasarkan Status Kesehatan dan Status Gizi

\begin{tabular}{|c|c|c|} 
Status & Status Gizi & Total \\
\hline
\end{tabular}

\begin{tabular}{|l|c|c|c|c|c|c|}
\hline \multirow{2}{*}{$\begin{array}{c}\text { Kesehata } \\
\mathbf{n}\end{array}$} & \multicolumn{2}{|c|}{$\begin{array}{c}\text { Normal } \\
\text { (n=32) }\end{array}$} & \multicolumn{2}{c|}{$\begin{array}{c}\text { Kurang } \\
(\mathbf{n = 3 9 )}\end{array}$} & \multicolumn{2}{|c|}{} \\
\cline { 2 - 7 } & $\mathbf{n}$ & $\%$ & $\mathbf{n}$ & $\%$ & $\mathbf{n}$ & $\%$ \\
\hline Sakit & 1 & 56.2 & 2 & 74.4 & 4 & 66.2 \\
& 8 & & 9 & & 7 & \\
\hline Tidak & 1 & 43.8 & 1 & 25.6 & 2 & 33.8 \\
Sakit & 4 & & 0 & & 4 & \\
\hline Total & 3 & 100. & 3 & 100. & 7 & 100. \\
& 2 & 0 & 9 & 0 & 1 & 0 \\
\hline
\end{tabular}

Jenis penyakit yang paling banyak diderita selama satu bulan terakhir adalah pilek (34.0\%). Jenis penyakit lain yang cukup banyak diderita anakanak adalah panas (17.0\%), batuk biasa $(17.0 \%)$ dan diare (14.9\%). Keadaan tersebut juga sama pada kedua kelompok status gizi. Bahkan pada kelompok status gizi normal, setengahnya dari jumlah total anak $(50 \%)$ pernah menderita pilek (Tabel 2). BPS (1994) menyatakan terdapat lima penyebab utama kematian bayi, yaitu tetanus, cedera kelahiran, infeksi saluran pernapasan, diare dan meningitis. Tiga penyakit utama yang memegang peranan sampai $60 \%$ kematian bayi adalah diare, infeksi saliran pernafasan dan tetanus (Aritonang 1996).

Tabel 2 menunjukkan pada umumnya $(87.2 \%)$ frekuensi sakit selama satu bulan terakhir adalah satu kali. Hal tersebut juga sama pada kedua kelompok status gizi. Hasil uji statistik tidak menunjukkan perbedaan yang nyata antara frekuensi sakit pada kelompok status gizi normal dengan kelompok status gizi kurang.

Tabel 2. Sebaran Anak Berdasarkan Frekuensi Sakit

\begin{tabular}{|c|c|c|c|c|c|c|}
\hline \multirow{3}{*}{ Frekuensi } & \multicolumn{4}{|c|}{ Status Gizi } & \multirow{2}{*}{\multicolumn{2}{|c|}{ Total }} \\
\hline & \multicolumn{2}{|c|}{$\begin{array}{c}\text { Normal } \\
(n=32)\end{array}$} & \multicolumn{2}{|c|}{$\begin{array}{c}\text { Kurang } \\
(n=39)\end{array}$} & & \\
\hline & n & $\%$ & $n$ & $\%$ & $\mathbf{n}$ & $\%$ \\
\hline $1 \mathrm{kali}$ & 15 & 83.3 & 26 & 89.6 & 41 & 87.2 \\
\hline 2 kali & 2 & 11.1 & 2 & 6.9 & 4 & 8.5 \\
\hline$\geq 3$ kali & 1 & 5.6 & 1 & 3.4 & 2 & 4.3 \\
\hline $\begin{array}{l}\text { Rata-rata } \\
\pm \text { std }\end{array}$ & \multicolumn{2}{|c|}{$\begin{array}{c}0.69 \\
\pm 0.74\end{array}$} & \multicolumn{2}{|c|}{$\begin{array}{c}1.03 \\
\pm 1.56\end{array}$} & \multicolumn{2}{|c|}{$\begin{array}{c}0.87 \pm \\
1.26\end{array}$} \\
\hline
\end{tabular}

Rata-rata anak mengalami sakit selama 3.46 hari. Pada kelompok 
status gizi normal, paling banyak $(44.4 \%)$ anak yang mengalami sakit selama 3 hari. Jumlah yang cukup tinggi ditemukan juga pada anak yang mengalami sakit selama 7 hari yaitu $22.2 \%$. Lain halnya pada kelompok status gizi kurang, jumlah paling tinggi ditemukan pada anak yang mengalami sakit selama 3 dan 7 hari yaitu masingmasing $31.0 \%$. Hasil penelitian menunjukkan rata-rata lama sakit pada kelompok status gizi normal lebih pendek (2.25 hari) dibandingkan kelompok status gizi kurang (4.46 hari) (Tabel 3). Hasil uji statistik menunjukkan terdapat perbedaan yang nyata antara lama sakit anak pada kelompok status gizi normal dengan kelompok status gizi kurang $(\alpha<0.05)$.

Tabel 3. Sebaran Contoh Berdasarkan Lama Sakit

\begin{tabular}{|c|c|c|c|c|c|c|}
\hline \multirow{3}{*}{$\begin{array}{c}\text { Lama } \\
\text { Sakit } \\
\text { (Hari) }\end{array}$} & \multicolumn{4}{|c|}{ Status Gizi } & \multirow{2}{*}{\multicolumn{2}{|c|}{ Total }} \\
\hline & \multicolumn{2}{|c|}{$\begin{array}{c}\text { Normal } \\
(n=32)\end{array}$} & \multicolumn{2}{|c|}{$\begin{array}{c}\text { Kurang } \\
(n=39)\end{array}$} & & \\
\hline & $\mathbf{n}$ & $\%$ & $\mathbf{n}$ & $\%$ & $\mathbf{n}$ & $\%$ \\
\hline 2 & 3 & 16.7 & 5 & 17.2 & 8 & 17.0 \\
\hline 3 & 8 & 44.4 & 9 & 31.0 & 17 & 36.2 \\
\hline 4 & 2 & 11.1 & 2 & 6.9 & 4 & 8.5 \\
\hline 5 & 0 & 0.0 & 0 & 0.0 & 0 & 0.0 \\
\hline 6 & 1 & 5.6 & 0 & 0.0 & 1 & 2.1 \\
\hline 7 & 4 & 22.2 & 9 & 31.0 & 13 & 27.7 \\
\hline $\begin{array}{l}\text { Lebih dari } \\
7 \text { hari }\end{array}$ & 0 & 0.0 & 4 & 13.8 & 4 & 8.5 \\
\hline $\begin{array}{l}\text { Rata-rata } \\
\pm \text { std }\end{array}$ & & $\begin{array}{l}25 \pm \\
45\end{array}$ & & $\begin{array}{l}46 \pm \\
47\end{array}$ & & $\begin{array}{l}46 \pm \\
49\end{array}$ \\
\hline
\end{tabular}

Jika dilihat berdasarkan skor morbiditasnya, maka diketahui bahwa skor morbiditas anak pada kelompok status gizi kurang lebih tinggi (201.03) dibandingkan skor morbiditas anak pada kelompok status gizi normal (150.94). Artinya anak kelompok status gizi kurang kondisi kesehatannya lebih buruk dibandingkan gizi normal. Tetapi walaupun demikian tidak menunjukkan perbedaan yang nyata antara skor morbiditas anak pada kelompok status gizi normal dengan kelompok status gizi kurang $(\alpha<0.05)$. Semakin tinggi skor morbiditas menunjukkan semakin parah suatu penyakit yang diderita atau bisa juga semakin lama dan sering anak mengalami sakit. Mora dan Netsel (2000) menyatakan bahwa gizi pada masa anak-anak secara langsung mempengaruhi sistem imun dan jika terjadi kekurangan gizi pada masa tersebut maka akan meningkatkan risiko morbiditas.

\section{Stimulasi Perkembangan Anak}

Proporsi tertinggi $(71.8 \%)$ keluarga yang melakukan stimulasi terdapat pada anak berumur 18-24 bulan. Sedangkan proporsi terendah (48.3\%) keluarga yang melakukan stimulasi ditemukan pada bayi berumur 0-30 hari. Jika dilihat berdasarkan kelompok status gizi, maka pada kelompok status gizi normal, proporsi terendah keluarga melakukan stimulasi terhadap bayi berumur 0-30 hari (44.\%) dan yang paling banyak keluarga melakukan stimulasi pada bayi berumur 3-4 tahun (75.0\%). Berbeda dengan kelompok status gizi normal, maka pada kelompok status gizi kurang, keluarga yang paling sedikit $(49.8 \%)$ melakukan stimulasi yaitu pada bayi berumur 2-3 tahun (49.8\%) dan keluarga yang paling banyak $(73.1 \%)$ melakukan stimulasi ditemukan pada saat bayi berumur 18-24 bulan. Berdasarkan data-data tersebut nampaknya terdapat perbedaan pola proporsi ibu yang melakukan stimulasi pada kedua kelompok status gizi tersebut.

Jenis stimulasi yang pada umumnya dilakukan pada bayi berumur 0-30 hari adalah memeluk bayi dengan kasih sayang ketika rewel $(62.0 \%)$ dan melatih menelungkupkan bayi $(60.6 \%)$. Kondisi tersebut juga terlihat pada anak dengan kelompok status gizi normal dan kurang. Hasil analisis menunjukkan bahwa proporsi ibu yang melakukan stimulasi perkembangan anak lebih tinggi pada kelompok status gizi kurang dibandingkan status gizi normal.

Tabel 4. Rata-rata Keluarga yang Melakukan Stimulasi terhadap Anak 


\begin{tabular}{|l|c|c|c|}
\multicolumn{2}{c}{} & \multicolumn{1}{c}{$\begin{array}{c}\text { Berdasarkan } \\
\text { Status Gizi }\end{array}$} & \multicolumn{1}{c}{ Umur } \\
\hline \multirow{3}{*}{ Umur } & \multicolumn{2}{|c|}{ Status Gizi } & Total \\
\cline { 2 - 4 } & $\begin{array}{c}\text { Normal } \\
(\mathbf{n = 3 2})\end{array}$ & $\begin{array}{c}\text { Kurang } \\
(\mathbf{n}=\mathbf{3 9})\end{array}$ & \\
\cline { 2 - 4 } & $\%$ & $\%$ & $\%$ \\
\hline 0-30 hari & 44.6 & 51.3 & 48.3 \\
\hline 1-4 bulan & 50.8 & 62.8 & 57.4 \\
\hline 4-6 bulan & 54.7 & 60.9 & 58.1 \\
\hline 6-9 bulan & 46.1 & 62.2 & 54.9 \\
\hline 9-12 bulan & 51.6 & 58.4 & 55.3 \\
\hline $\begin{array}{l}\text { 12-18 } \\
\text { bulan }\end{array}$ & 56.3 & 60.3 & 58.5 \\
\hline $\begin{array}{l}\text { 18-24 } \\
\text { bulan }\end{array}$ & 71.1 & 73.1 & 71.8 \\
\hline 2-3 tahun & 62.2 & 49.8 & 54.5 \\
\hline 3-4 tahun & 75.0 & 60.0 & 62.5 \\
\hline
\end{tabular}

Jenis stimulasi lainnya adalah meletakkan benda yang bergerakgerak di atas bayi yang dilakukan sekitar $50 \%$ ibu, dan hanya $25 \%$ ibu yang melakukan stimulasi dengan cara mengajak tersenyum. Jika dibandingkan berdasarkan kelompok status gizi, maka proporsi ibu yang melakukan stimulasi pada bayi berumur 0-30 hari lebih tinggi pada kelompok status gizi kurang. Anggota keluarga yang berperan dalam stimulasi tersebut hampir seluruhnya dilakukan oleh ibu $(100 \%)$.

Hasil analisis menunjukkan bahwa stimulasi yang paling banyak dilakukan pada bayi berumur 1-4 bulan adalah mengajak bicara, menirukan gerak dan mimik bayi, diperdengarkan suara lainnya $(70.4 \%)$, melatih bayi membalik badan $(69.0 \%)$ dan melatih bayi menggenggam (54.9\%). Sedangkan memeluk, mencium, menyanyikan lagu dan membuainya hanya dilakukan sekitar $35.2 \%$ ibu. Proporsi ibu yang melakukan stimulasi lebih banyak ditemukan pada status gizi kurang terutama dalam hal memeluk, mencium, menyanyikan lagu dan membuainya (43.6\%), mengajak bicara, menirukan gerak dan mimik bayi, diperdengarkan suara lainnya $(79.5 \%)$ dan melatih bayi menggenggam (66.7\%). Sedangkan jumlah ibu yang melatih bayi membalik badan lebih banyak ditemukan pada kelompok status gizi normal $(78.1 \%)$.

Anggota keluarga yang berperan dalam stimulasi perkembangan didominasi oleh ibu. Walaupun jumlahnya sedikit, pada saat bayi 1-4 bulan sudah terlihat adanya keterlibatan ayah dan anggota lainnya dalam memberikan stimulasi. Pada kelompok status gizi normal, ayah banyak terlibat dalam melatih bayi membalik badan (12.5\%), sedangkan pada kelompok status gizi kurang, ayah banyak terlibat dalam melatih bayi menggenggam (11.5\%).

Lebih dari $50 \%$ ibu melakukan stimulasi pada bayi 4-6 bulan dalam melatih menggunakan kedua tangan memegang benda (60.6\%), melatih bayi menirukan bunyi agar ditirukan $(77.5 \%)$ dan melatih bayi menirukan bunyi $(59.2 \%)$. Sedangkan stimulasi lain yaitu melatih bayi didudukkan, dilakukan oleh sekitar $35.2 \%$ ibu. Pola stimulasi tersebut ditemukan pada kedua kelompok anak dengan status gizi yang berbeda. Walaupun proporsi ibu yang melakukan stimulasi pada kelompok status gizi kurang lebih tinggi dibandingkan kelompok status gizi normal. Pada bayi usia 4-6 bulan, keterlibatan anggota keluarga lain dalam melakukan stimulasi sudah semakin meningkat. Peran bapak pada umumnya adalah melatih bayi menirukan bunyi agar ditirukan dan melatih bayi duduk. Hal tersebut terlihat pada kedua kelompok status gizi. Pada kelompok status gizi kurang, kegiatan stimulasi hanya melibatkan ibu dan bapak saja dan tidak menunjukkan keterlibatan anggota lainnya. Sedangkan pada kelompok status gizi normal, selain melibatkan ibu dan bapak juga melibatkan anggota lainnya.

Pada kelompok status gizi kurang, proporsi tertinggi ibu melakukan stimulasi terhadap bayi berumur 6-9 bulan. Stimulasi tersebut meliputi melatih mengangkat bayi untuk berdiri (64.1\%), melatih bayi memasukan/mengeluarkan benda dari 
suatu wadah (56.4\%), memperlihatkan gambar dan menyebutkan namanya $(61.5 \%)$ dan mengajak bayi dengan cara/bentuk permainan bersama-sama $(66.7 \%)$. Sedangkan untuk kelompok status gizi normal, proporsi tertinggi ibu $(53.1 \%)$ melakukan stimulasi hanya ditemukan pada beberapa hal seperti memperlihatkan gambar dan menyebutkan namanya dan mengajak bayi dengan cara/bentuk permainan bersama-sama. Meskipun peran stimulasi didominasi oleh ibu, tetapi sudah memperlihatkan peran ayah dan anggota lainnya. Stimulasi yang banyak dilakukan oleh ayah dan anggota lainnya pada bayi berumur 6-9 bulan adalah memperlihatkan gambar dan menyebutkan namanya.

Kegiatan stimulasi yang paling banyak dilakukan (lebih dari 70\%) pada bayi usia 9-12 bulan adalah melatih berjalan berdiri. Stimulasi lainnya yang banyak dilakukan (sekitar 67.6\%) ibu adalah melatih bayi corat-coret. Sebaliknya untuk melatih bayi menggelindingkan bola hanya dilakukan sekitar $45 \%$ ibu, bahkan mengajak bayi makan bersama keluarga hanya dilakukan oleh sebagian kecil ibu (32.4\%). Keadaan tersebut juga terlihat pada kedua kelompok status gizi. Sama halnya dengan usia-usia sebelumnya, pada bayi usia 9-12 bulan stimulasi cenderung lebih banyak dilakukan pada kelompok status gizi kurang. Pada usia tersebut juga memperlihatkan adanya keterlibatan anggota keluarga lain selain ibu. Pada kedua kelompok status gizi, proporsi tertinggi keterlibatan ayah adalah dalam hal melatih bayi berjalan berdiri.

Pada umumnya (lebih dari $60 \%$ ) ibu melakukan stimulasi terhadap bayi berumur 12-18 bulan, seperti melatih anak naik turun tangga (rumah) $(60.6 \%)$, melatih menunjuk dan menyebut bagian tubuh $(62.0 \%)$ dan memberi kesempatan anak melepas baju $(71.8 \%)$. Sedangkan bermain melempar dan menangkap bola hanya dilakukan oleh sebagian kecil ibu
(39.4\%). Pola tersebut juga terlihat pada kedua kelompok status gizi. Proporsi ibu yang melatih anak naik turun tangga (rumah) lebih tinggi pada kelompok status gizi normal, sedangkan untuk stimulasi lainnya lebih banyak dilakukan oleh ibu pada kelompok status gizi kurang. Dominasi ibu dalam memberikan stimulasi masih terlihat pada bayi usia 12-18 bulan. Pada kelompok status gizi normal, ayah berperan dalam memberikan stimulasi dalam hal bermain melempar dan menangkap bola (8.3\%) serta memberi kesempatan anak melepas baju (9.5\%). Sedangkan pada kelompok status gizi kurang, ayah memberikan stimulasi dalam hal melatih anak naik turun tangga (rumah) $(4.8 \%)$ dan melatih menunjuk dan menyebut bagian tubuh (3.7\%).

Sebagian besar ibu (lebih dari $75 \%)$ melakukan stimulasi terhadap bayi berumur 18-24 bulan. Jenis stimulasi tersebut meliputi melatih anak menggambar bulatan dan segitiga $(82.3 \%)$, melatih anak menceritakan apa yang dilihatnya $(80.6 \%)$ serta melatih anak tentang kebersihan diri (buang air kecil/besar pada tempatnya (75.8\%). Sedangkan melatih keseimbangan anak dengan berdiri satu kaki bergantian hanya dilakukan oleh $48.4 \%$ ibu. Jika dilihat berdasarkan kelompok status gizi, maka secara umum proporsi ibu yang melakukan stimulasi lebih tinggi pada kelompok status gizi kurang. Pada bayi berumur 18-24 bulan, peran ayah masih terlihat, tetapi proporsi anggota keluarga lainnya lebih tinggi (lebih dari $30 \%)$ dalam memberikan stimulasi, terutama dalam melatih keseimbangan anak berdiri dengan satu kaki bergantian dan melatih menggambar bulatan, segitiga. Kondisi tersebut terlihat pada kelompok status gizi normal maupun kurang.

Berbeda dengan umur-umur bayi sebelumnya, maka pada bayi berumur 2-3 tahun, proporsi ibu yang melakukan stimulasi lebih tinggi pada kelompok status gizi normal daripada status gizi 
kurang. Lebih dari $50 \%$ ibu pada kelompok status gizi normal melakukan stimulasi dalam bentuk melatih anak melompat dengan satu kaki (56.3\%), melatih anak mengenal bentuk benda dan warnanya (68.8\%) dan melatih anak tentang kebersihan diri $(80.0 \%)$. Sementara melatih anak menyusun balok hanya dilakukan oleh $43.8 \%$. Lain halnya pada kelompok status gizi kurang, proporsi ibu tertinggi tidak melakukan stimulasi. pada bayi berumur 2-3 tahun dan bentuk stimulasi yang diberikan hanya melatih anak mengenal bentuk benda dan warnanya (66.7\%) Proporsi anggota lainnya cukup tinggi dalam memberikan stimulasi terutama dalam melatih anak menyusun balok. Jenis stimulasi ini juga banyak dilakukan oleh ayah pada anaknya.

Pada penelitian ini ditemukan satu orang balita berumur 3-4 tahun termasuk dalam status gizi normal. Jenis stimulasi yang diberikan pada bayi tersebut terdiri dari memberi kesempatan anak melompat dengan satu kaki, melatih memotong gambar dan melatih sopan santun. Sedangkan jenis stimulasi yang tidak dilakukan adalah melatih mengancingkan baju. Lain halnya dengan ibu yang termasuk status gizi kurang, proporsi tertinggi ibu $(71.4 \%)$ melakukan stimulasi dalam bentuk melatih memotong gambar dan melatih mengancingkan baju. Dominasi ibu dalam memberikan stimulasi terlihat pada kelompok status gizi normal. Sedangkan pada kelompok status gizi kurang, terlihat adanya keterlibatan ayah dalam melatih anak melompok dengan satu kaki $(50.0 \%)$ dan peran anggota lainnya dalam hal melatih anak memotong gambar.

Berdasarkan data-data diatas maka dapat dikatakan bahwa pemberian stimulasi cenderung lebih banyak di lakukan oleh ibu pada kelompok status gizi kurang dibandingkan dengan kelompok status gizi normal. Jika dilihat berdasarkan kategori stimulasi, maka proporsi terbanyak berada pada kategori rendah (66.2\%). Hal ini menunjukkan bahwa peran anggota keluarga dalam memberi stimulasi masih kurang. Walaupun demikian masih ditemukan sebanyak $9.9 \%$ ibu yang memiliki kategori stimulasi sedang dan $23.9 \%$ berkategori baik. Tingginya proporsi ibu yang memiliki kategori stimulasi kurang diduga karena keluarga yang menjadi ibu dalam penelitian ini adalah keluarga miskin, yang umumnya kurang perhatian terhadap perkembangan anaknya. Hal ini sesuai dengan pendapat Kasuma (2001) bahwa keadaan ekonomi dapat mempengaruhi pengasuhan orang tua terhadap anaknya. Keluarga dengan tingkat ekonomi rendah umumya kurang memberi perhatian terhadap perilaku anak dan kurang latihan. Sedangkan pada keluarga dengan ekonomi cukup menyebabkan orang tua lebih punyak waktu untuk membimbing anaknya karena tidak lagi memikirkan keadaan ekonomi yang kurang. Grantham-McGregor (1995) menyatakan bahwa keluarga dengan tingkat ekonomi rendah, kurang dalam memberikan stimulasi, sedikit alat permainan dan kurangnya partisipasi orang tua dalam aktivitas bermain anak.

Jika dilihat berdasarkan kelompok status gizi maka sebagian besar memiliki kategori stimulasi kurang. Pada Tabel 5 dapat dilihat bahwa kategori stimulasi tinggi lebih banyak ditemukan pada kelompok status gizi kurang (30.8\%) dibandingkan kelompok status gizi normal (15.6\%). Sebaliknya kategori distimulasi rendah lebih banyak ditemukan pada kelompok status gizi normal (75\%).

Hasil analisis juga menunjukkan bahwa skor stimulasi pada kelompok status gizi kurang (57.82) lebih tinggi dibandingkan kelompok status gizi normal (53.81) (Tabel 5), walaupun secara statistik tidak menunjukkan perbedaan nyata $(\alpha<0.05)$. Semakin tinggi skor stimulasi maka semakin banyak stimulasi atau rangsangan perkembangan anak yang diberikan. 
Menurut Gunarsa dan Gunarsa (1995) mengatakan semakin banyak rangsangan dari lingkungan maka makin luas pengetahuannya sehingga perkembangan anak semakin optimal. Selanjutnya Hawadi (2001) mengatakan jika anak kurang mendapatkan stimulasi maka anak akan menjadi pasif dan tidak kreatif sehingga perkembangannya kurang optimal.

Tabel 5. Sebaran Status Gizi Anak berdasarkan Stimulasi

\begin{tabular}{|c|c|c|c|c|c|c|}
\hline \multirow{3}{*}{$\begin{array}{l}\text { Kategori } \\
\text { Stimulasi }\end{array}$} & \multicolumn{4}{|c|}{ Status Gizi } & \multirow{2}{*}{\multicolumn{2}{|c|}{ Total }} \\
\hline & \multicolumn{2}{|c|}{$\begin{array}{c}\text { Normal } \\
(n=32)\end{array}$} & \multicolumn{2}{|c|}{$\begin{array}{c}\text { Kurang } \\
(n=39)\end{array}$} & & \\
\hline & $n$ & $\%$ & $\mathbf{n}$ & $\%$ & $\mathbf{n}$ & $\%$ \\
\hline Renc & 24 & 75 & 23 & 59.0 & 47 & 66.2 \\
\hline Seda & 3 & 9.4 & 4 & 10.3 & 7 & 9.9 \\
\hline Tinggi & 5 & 15.6 & 12 & 30.8 & 17 & 23.9 \\
\hline $\begin{array}{l}\text { Rata-rata } \\
\text { std }\end{array}$ & \multicolumn{2}{|c|}{$\begin{array}{c}53.81 \pm \\
26.75\end{array}$} & \multicolumn{2}{|c|}{$\begin{array}{c}57.82 \pm \\
28.45\end{array}$} & \multicolumn{2}{|c|}{$\begin{array}{c}56.01 \pm \\
27.58\end{array}$} \\
\hline
\end{tabular}

Data-data diatas juga menunjukkan bahwa peran ibu dalam memberikan stimulasi sangat tinggi, sedangkan keterlibatan ayah dan anggota lainnya masih rendah. Sularyo (1993) menyatakan bahwa peran seorang ibu sangat besar, tidak hanya mengasuh tetapi juga dalam memberikan stimulasi mental pada anaknya. Hubungan ibu dan anak merupakan interaksi sosial yang pertama kali dialami oleh anak, kemudian meluas kepada ayah dan anggota lain atau pengasuh. Selanjutnya Spock (1982) menyatakan bahwa seorang ayah yang bijaksana akan menyadari bahwa dia turut bertanggung jawab dalam pengasuhan anaknya, mulai anak lahir sampai dewasa. Seorang ayah dapat melakukan berbagai cara untuk mengoptimalkan perkembangan anak balitanya. Ayah dapat membantu anak menguasai konsep obyek permanen dengan menyediakan alat permainan dan mengajak berbicara mengenai konsep tersebut. Ayah juga dapat memperkenalkan konsep angka, bentuk, kata, ukuran dan sebagainya pada anaknya. Sambil bertamasya atau jalan-jalan, ayah dapat menyebutkan nama benda atau obyek yang dilihat. Kegiatan ini akan merangsang perkembangan kognitif serta menambah perbendaharaan bahasa anak (Nurhaena 1995). Hasil penelitian Kasuma (2001) di Nusa Tenggara Timur menujukkan bahwa peran ayah dalam pengasuhan mempunyai pengaruh nyata pada tingkat perkembangan anak.

\section{Perkembangan Anak}

Hasil penelitian menunjukkan bahwa sebagian besar $(73.2 \%)$ contoh anak memiliki tingkat perkembangan normal. Sedangkan anak yang memiliki perkembangan cepat hanya $5.6 \%$ dan yang perkembangannya lambat mencapai $21.1 \%$ (Tabel 6). Keadaan yang sama juga terlihat pada kedua kelompok status gizi, dimana sebagian besar memiliki tingkat perkembangan normal. Hasil penelitian menunjukkan adanya kecenderungan bahwa perkembangan anak lebih baik pada kelompok status gizi kurang. Meskipun dengan uji statistik perbedaan tersebut tidak signifikan. Stimulasi perkembangan anak yang lebih tinggi (intensif) pada kelompok status gizi kurang kemungkinan menyebabkan perkembangan anak tersebut relatif lebih baik. Perbedaan metode pengukuran antara status gizi dengan perkembangan dilakukan dengan time reference yang berbeda. Status gizi anak dinilai pada kondisi saat ini, sedangkan perkembangan anak dinilai secara akumulatif sejak lahir sampai dengan usia saat diukur. Usia anak pada kelompok status gizi kurang lebih tua (29 bulan) dibandingkan dengan anak yang status gizi normal ( 25 bulan). 
Tabel 6. Sebaran

Perkembangan dan Status Gizi Anak

\begin{tabular}{|c|c|c|c|c|c|c|}
\hline \multirow{3}{*}{$\begin{array}{c}\text { Kategori } \\
\text { Perkem- } \\
\text { bangan } \\
\text { Anak }\end{array}$} & \multicolumn{4}{|c|}{ Status Gizi } & \multicolumn{2}{|c|}{$\begin{array}{c}\text { Total } \\
(n=71)\end{array}$} \\
\hline & \multicolumn{2}{|c|}{ Normal } & \multicolumn{2}{|c|}{ Kurang } & & \\
\hline & $\mathbf{n}$ & $\%$ & $\mathbf{n}$ & $\%$ & $\mathbf{n}$ & $\%$ \\
\hline Cepat & 0 & 0.0 & 4 & 10.3 & 4 & 5.6 \\
\hline Normal & 25 & 78.1 & 27 & 69.2 & 52 & 73.2 \\
\hline Lambat & 7 & 21.9 & 8 & 20.5 & 15 & 21.1 \\
\hline Skor & \multicolumn{2}{|c|}{$\begin{array}{c}26.34 \pm \\
3.05\end{array}$} & \multicolumn{2}{|c|}{$\begin{array}{c}27.26 \pm \\
4.36\end{array}$} & \multicolumn{2}{|c|}{$\begin{array}{c}26.85 \pm \\
3.05\end{array}$} \\
\hline
\end{tabular}

UNICEF (1998) mengatakan bahwa stimulasi yang diberikan oleh orang tua dan pengasuh sangat mendukung terhadap perkembangan anak yang optimal. Sementara Monks, dkk (1992) mengatakan bahwa stimulasi verbal sangat penting bagi perkembangan bahasa dalam periode tahun pertama. Bayi-bayi yang sering diajak bicara oleh ibu-ibu mereka memiliki tingkat perkembangan yang lebih tinggi daripada bayi yang tidak mengalami perlakuan tersebut.

Jika dilihat berdasarkan kategori stimulasi maka pada umumnya perkembangan anak termasuk normal. Kondisi tersebut terlihat pada kategori stimulasi rendah, sedang maupun tinggi (Tabel 7). Walaupun demikian masih ditemukan perkembangan anak yang lambat, terutama pada kategori stimulasi rendah dan sedang. Pada kategori stimulasi tinggi tidak ditemukan adanya perkembangan anak yang lambat. Hasil uji Spearman menunjukkan terdapat hubungan positif nyata antara stimulasi dengan perkembangan anak. Hal ini berarti semakin banyak anak diberi stimulasi maka perkembangannya semakin baik. Menurut Gunarsa dan Gunarsa (1995) semakin banyak anak menerima stimulasi dari lingkungan semakin luas pengetahuannya sehingga perkembangannya akan optimal. Demikian juga Alisjahbana (2000) mengatakan bahwa perkembangan anak dapat didukung dan dirangsang dari lingkungan.
Tabel 7. Sebaran Anak Berdasarkan Kategori Stimulasi dan Perkembangan

\begin{tabular}{|l|r|r|r|r|r|r|}
\hline \multirow{2}{*}{$\begin{array}{c}\text { Kategori } \\
\text { Perkembang } \\
\text { an Anak }\end{array}$} & \multicolumn{5}{|c|}{ Kategori Stimulasi } \\
\cline { 2 - 7 } & \multicolumn{2}{|c|}{ Rendah } & \multicolumn{2}{|c|}{ Sedang } & \multicolumn{2}{|c|}{ Tinggi } \\
\cline { 2 - 7 } & $\mathbf{n}$ & \multicolumn{1}{c}{$\%$} & $\mathbf{n}$ & \multicolumn{1}{c}{$\%$} & $\mathbf{n}$ & \multicolumn{1}{c|}{$\%$} \\
\hline Lambat & 1 & 27.7 & 2 & 28.6 & 0 & 0.0 \\
& 3 & & & & & \\
\hline Normal & 3 & 66.0 & 5 & 71.4 & 1 & 94.1 \\
& 1 & & & & 6 & \\
\hline Cepat & 3 & 6.4 & 0 & 0.0 & 1 & 5.9 \\
\hline Total & 4 & 100. & 7 & 100. & 1 & 100. \\
& 7 & 0 & & 0 & 7 & 0 \\
\hline
\end{tabular}

Jika dilihat berdasarkan jenis kelamin, maka perkembangan anak pada umumnya normal. Pada Tabel 8 terlihat bahwa kategori perkembangan anak yang lambat $(25.6 \%)$ dan cepat $(7.7 \%)$ lebih banyak ditemukan pada anak laki-laki daripada perempuan. Pada anak perempuan ditemukan sebanyak $\quad 15.6 \% \quad$ memiliki perkembangan lambat dan $3.1 \%$ termasuk cepat. Hasil uji Spearman tidak menunjukkan adanya hubungan nyata antara jenis kelamin dengan perkembangan anak $(\alpha<0.05)$.

Tabel 8. Sebaran Kategori Perkembangan dan Jenis Kelamin Anak

\begin{tabular}{|l|r|c|r|c|}
\hline \multirow{2}{*}{$\begin{array}{c}\text { Kategori } \\
\text { Perkembangan }\end{array}$ Anak } & \multicolumn{4}{|c|}{ Jenis Kelamin } \\
\cline { 2 - 5 } & \multicolumn{1}{|c|}{ Laki-laki } & \multicolumn{2}{c|}{ Perempuan } \\
\cline { 2 - 5 } & $\mathbf{n}$ & \multicolumn{1}{c|}{ \% } & $\mathbf{n}$ & \% \\
\hline Lambat & 10 & 25.6 & 5 & 15.6 \\
\hline Normal & 26 & 66.7 & 26 & 81.3 \\
\hline Cepat & 3 & 7.7 & 1 & 3.1 \\
\hline Total & 39 & 100.0 & 32 & 100.0 \\
\hline
\end{tabular}

Hal yang sama juga terlihat bahwa pada umumnya perkembangan anak normal, baik pada kelompok umur 1224 bulan maupun 25-60 bulan. Pada penelitian ini ditemukan proporsi anak yang memiliki perkembangan lambat cukup tinggi $(41.7 \%)$, terutama pada kelompok umur 12-24 bulan (Tabel 9). Sedangkan anak yang memiliki perkembangan yang cepat hanya ditemukan pada kelompok usia 25-60 bulan. Hasil uji Spearman menunjukkan adanya hubungan positif sangat nyata antara umur anak dengan 
perkembangan. Hal ini berarti semakin meningkat umur anak maka perkembanganya akan semakin baik $(\alpha<0.01)$.

Tabel 9. Sebaran Kategori Perkembangan dan Umur Anak

\begin{tabular}{|l|l|l|l|l|}
\hline \multirow{2}{*}{$\begin{array}{c}\text { Kategori } \\
\text { Perkembangan Anak }\end{array}$} & \multicolumn{4}{|c|}{ Umur Anak } \\
\cline { 2 - 5 } & $\begin{array}{c}\mathbf{1 2 - 2 4} \\
\text { bln }\end{array}$ & \multicolumn{2}{c|}{$\begin{array}{c}\mathbf{2 5 - 6 0} \\
\text { bln }\end{array}$} \\
\cline { 2 - 5 } & $\mathbf{n}$ & $\mathbf{9}$ & $\mathbf{n}$ & $\%$ \\
\hline Lambat & 10 & 41.7 & 5 & 10.6 \\
\hline Normal & 14 & 58.3 & 38 & 80.9 \\
\hline Cepat & 0 & 0 & 4 & 8.5 \\
\hline Total & 24 & 100 & 47 & 100 \\
\hline
\end{tabular}

SIMPULAN DAN SARAN

1. Karakteristik keluarga antara kelompok anak dengan status gizi normal dan kurang relatif sama, yaitu umur antara 27-33 tahun, tingkat pendidikan Sekolah Dasar, ibu tidak bekerja, ayah sebagai buruh, pendapatan rumah tangga 500-600 ribu rupiah per bulan, jumlah anggota rumah tangga lima, jumlah anak balita satu orang, serta keadaan lingkungan rumah yang sederhana.

2. Stimulasi terhadap perkembangan anak hanya dilakukan oleh $48-72 \%$ keluarga. Sehingga sebagian keluarga miskin ini kategori stimulasinya rendah (66.2\%). Proporsi keluarga yang melakukan stimulasi pada anak dengan status gizi kurang lebih tinggi dibandingkan dengan kelompok status gizi normal. Sebagian besar stimulasi diberikan oleh ibu dari pada ayah atau anggota keluarga lainnya, sedangkan sebagian kecil stimulasi dilakukan untuk setiap kelompok umur, kecuali anak berusia 0-30 hari dan 3-4 tahun. Sebagian kecil anggota keluarga lainnya juga berperan didalam melakukan stimulasi, dan dijumpai pada setiap kelompok umur anak.

3. Perkembangan anak kebanyakan berada pada kategori normal
(73\%). Kategori lambat diketemukan pada kelompok anak gizi normal dan kurang (masingmasing $22 \%$ dan $21 \%$ ). Pemberian stimulasi berkorelasi dengan nilai perkembangan anak. Pada kategori stimulasi tinggi tidak dijumpai anak yang kategori perkembangannya lambat. Meskipun skor perkembangan anak gizi kurang sedikit lebih tinggi dibandingkan gizi baik, tetapi secara statistik tidak signifikan. Diduga metode pengukuran variabel perkembangan dan pertumbuhan dengan time references yang berbeda mempengaruhi nilai skor tersebut.

4. Kesimpulan di atas menegaskan kembali perlunya stimulasi terhadap anak sejak usia dini. Stimulasi dapat diberikan secara internal oleh keluarga, institusi kemasyarakatan, maupun melalui program pemerintah. Karena masih rendahnya stimulasi yang diberikan oleh internal keluarga, maka disarankan program pemerintah terhadap early child development seperti BKB dan PADU tetap terus dikembangkan dan dilanjutkan.

\section{UCAPAN TERIMA KASIH}

Penulis menyampaikan terima kasih kepada Tim Peneliti kerjasama PSKPG-IPB dan WFP yang telah mengijinkan penggunaan kerangka sampel untuk studi ini.

\section{DAFTAR PUSTAKA}

Alisjahbana, A. 2000. Stimulasi PsikoSosial, Tumbuh Kembang, Pola Asuh dan Hak Anak. Makalah Disampaikan pada Pelatihan Bagi Media Massa: Konvensi Hal-Hak Anak Serta Pangan dan Gizi. Pusat Penelitian dan Pengembangan Gizi, November 2000, Bogor.

Aritonang, I. 1996. Pemantauan Pertumbuhan Balita. Jakarta: Kanisius.

[BPS] Badan Pusat Statistik. 1994. Tren Fertilitas, Mortalitas dan Migrasi. Jakarta: BPS.

[Depkes] Departemen Kesehatan RI. 2000. Penanggulangan Anak-anak yang 
Terpuruk Akibat Krisis. Disampaikan pada Konferensi Nasional III Kesejahteraan Anak, 26-28 Oktober, Jakarta.

[Depkes] Departemen Kesehatan RI dan JICA. 2000. Buku Kesehatan Ibu dan Anak. Jakarta.

Engle, P.L., P. Menon, L. Haddad. 1997. Care and Nutrition: Concepts and Measurement. International Food Policy Research Institute.

Grantham-McGregor, S. 1995. A review of studies of the effect of severe malnutrition on mental development. J. Nutr. (suppl) : 125: 85

Gunarsa, S.D., S.D. Gunarsa. 1995. Psikologi untuk Keluarga. Jakarta: BPK Gunung Mulia.

Hawadi, R.A. 2001. Psikologi Perkembangan Anak: Mengenal Sifat, Bakat dan Kemampuan Anak. Jakarta: Gramedia Widiasarana Indonesia.

Kasuma, N.O.K. 2001. Pola Asuh dan tumbuh kembang anak balita pada keluarga etnik Timor dan Rote di Kabupaten Kupang, Nusa Tenggara Timur [skripsi]. Bogor: Jurusan Gizi Masyaraka dan Sumberdaya Keluarga, Faperta, IPB.

Megawangi, R. 1999. Membiarkan Berbeda: Sudut Pandang baru Relasi Gender. Bandung: Mizan Pustaka.

Muchtadi, D. 1996. Gizi Untuk Bayi. Jakarta: Sinar Harapan.
Monks, F.J., A.M.P. Knoers, S.R. Haditono. 1992. Psikologi Perkembangan. Yogyakarta: Gajah Mada University Press.

Nurhaena. 1995. Keterlibatan ayah dalam pengasuhan bayi dan anak kecil [skripsi]. Jakarta: Fakultas Psikologi, Universitas Indonesia.

Pudjiadi, S. 2001. IImu Gizi Klinis pada Anak. Edisi keempat. Jakarta: Fakultas Kedokteran, Universitas Indonesia.

Satoto. 1990. Pertumbuhan dan perkembangan anak: pengamatan 018 bulan di Kecamatan Mlonggo, Kabupaten Jepara, Jawa Tengah [disertasi]. Semarang: Universitas Diponegoro.

UNICEF. 1998. The State of The World's Children 1998. New York: Oxford University Press.

Victoria, C.G., et al. 1999. Potential intervention for the prevention of childhood pneumonia in developing countries: improving nutrition. Am.Clin.J.Nutr, 70: 309-20

Zeitlin, M. 2000. Peran Pola Asuh Anak : Pemanfaatan Hasil Studi Penyimpangan Positif Untuk Program Gizi. Widyakarya Nasional Pangan dan Gizi VII, LIPI, Jakarta.

1 Staf Pengajar Departemen Gizi Masyarakat, FEMA IPB

2 Staf Pengajar Departemen IImu Keluarga dan Konsumen, FEMA IPB 